\title{
Evaluation of sanitization treatments for red amaranthus (Amaranthus tricolor L.)
}

\author{
- Geogy Mariam George ${ }^{1 *}$, P.R. Geetha Lekshmi ${ }^{1}$, C. Mini ${ }^{1}$, K.N. Anith² and R.V. \\ $\mathrm{MANJU}^{3}$
}

${ }^{1}$ Department of Processing Technology, College of Agriculture, Vellayani, THIRUVANATHAPURAM (KERALA) INDIA

${ }^{2}$ Department of Microbiology, College of Agriculture, Vellayani, THIRUVANATHAPURAM (KERALA) INDIA

${ }^{3}$ Department of Plant Physiology, College of Agriculture, Vellayani, THIRUVANATHAPURAM (KERALA) INDIA

Email : gmaryg7@gmail.com; geetha_lekshmy@yahoo.co.in and minichandran123@gmail.com

*Author for Correspondence

Research chronicle : Received : 24.08.2015; Revised : 17.10.2015; Accepted : 20.11.2015

\section{SUMMARY :}

Amaranthus is known as 'poor man's spinach' which is most commonly used leafy vegetable rich in nutrients. Increased need of sanitization in postharvest handling of leafy vegetables has been reported due to outbreak of disease causing pathogens and also due to huge postharvest loss. In the present study amaranthus (var. Arun) were sanitized with different sanitizing agents viz., ozonised water, sodium hypochlorite, brine and tap water (control). Effectiveness of these sanitizing agents for surface decontamination of harvested amaranthus was evaluated by analyzing microbial, physiological and visual parameters. The results revealed that amaranthus sanitized with $2 \mathrm{ppm}$ ozonised water had highest microbial reduction $(85.68 \%)$, lowest physiological loss in weight $(25.63 \%)$, highest relative water content $(63.11 \%)$ and highest score for visual parameters and overall acceptability which was followed by the treatment with $30 \mathrm{ppm}$ sodium hypochlorite. Sanitization with $2 \mathrm{ppm}$ ozonised water also extended the shelf-life of amaranthus upto $4 \mathrm{~h}$ of storage at room temperature.

KEY WORDS : Sanitization, Amaranthus, Ozonised water, Sodium hypochlorite, Shelf-life

How to cite this paper : George, Geogy Mariam, Lekshmi, P.R. Geetha, Mini, C., Anith, K.N. and Manju, R. V. (2015). Evaluation of sanitization treatments for red amaranthus (Amaranthus tricolor L.). Internat. J. Proc. \& Post Harvest Technol., 6 (2) : 144-149. 